\title{
Tenacibaculosis infection in marine fish caused by Tenacibaculum maritimum: a review
}

\author{
Ruben Avendaño-Herrera, Alicia E. Toranzo, Beatriz Magariños* \\ Departamento de Microbiología y Parasitología, Facultad de Biología e Instituto de Acuicultura, Universidad de Santiago, \\ 15782 Santiago de Compostela, Spain
}

\begin{abstract}
Tenacibaculum maritimum is the aetiological agent of an ulcerative disease known as tenacibaculosis, which affects a large number of marine fish species in the world and is of considerable economic significance to aquaculture producers. Problems associated with epizootics include high mortality rates, increased susceptibility to other pathogens, high labour costs of treatment and enormous expenditures on chemotherapy. In the present article we review current knowledge on this bacterial pathogen, focusing on important aspects such as the phenotypic, serologic and genetic characterization of the bacterium, its geographical distribution and the host species affected. The epizootiology of the disease, the routes of transmission and the putative reservoirs of T. maritimum are also discussed. We include a summary of molecular diagnostic procedures, the current status of prevention and control strategies, the main virulence mechanisms of the pathogen, and we attempt to highlight fruitful areas for continued research.
\end{abstract}

KEY WORDS: Tenacibaculum maritimum $\cdot$ Tenacibaculosis $\cdot$ Review $\cdot$ Pathogenicity $\cdot$ Diagnosis Control Resale or republication not permitted without written consent of the publisher

\section{INTRODUCTION}

Tenacibaculum maritimum, a Gram-negative and filamentous bacterium, has been described as the etiological agent of tenacibaculosis in marine fish. The pathology of the disease caused by this marine organism has mainly been associated with characteristic gross lesions on the body surface of fish such as ulcers, necrosis, eroded mouth, frayed fins and tail rots, and sometimes necrosis on the gills and eyes (McVicar \& White 1979, Campbell \& Buswell 1982, Wakabayashi et al. 1984, Baxa et al. 1986, Devesa et al. 1989, Alsina \& Blanch 1993, Chen et al. 1995, Handlinger et al. 1997, Ostland et al. 1999, Cepeda \& Santos 2002). However, due to some variation in external pathological signs of the disease, depending on the species and age of fish, some authors have used different names to designate this ulcerative condition (see reviews by Bernardet 1998 and Santos et al. 1999). For example, the names salt water columnaris disease, gliding bacterial disease of sea fish, bacterial stomatitis, eroded mouth syndrome and black patch necrosis have all been used. To avoid confusion with other fish diseases, this review will use the name tenacibaculosis.

To date, tenacibaculosis is one of the most threatening bacterial infections limiting the culture of many species of commercial value in distinct geographical areas of the world (see review by Toranzo et al. 2005). Therefore, the aim of this article is to compile the current state of knowledge of the disease caused by Tenacibaculum maritimum, focusing on important aspects such as a phenotypic, serological and genetic characterization of the bacterium, and a description of the pathogen's geographical distribution and the host species affected. In addition, methods to diagnose together with strategies to prevent the disease and its main virulence mechanisms have also been addressed. Our hope is that this review will highlight important directions for future research on this fish pathogen. 


\section{TAXONOMY}

The taxonomy of Tenacibaculum maritimum was a matter of controversy and confusion for decades, and it has only recently been clarified by Suzuki et al. (2001). Masumura \& Wakabayashi (1977) isolated a gliding bacterium that had caused mass mortalities among certain cultured marine fish. These strains were characterized by Hikida et al. (1979), who announced their intention to make a separate formal proposal of the name Flexibacter marinus. Since the epithet marinus had already been used in the name Vibrio marinus, the authors changed their mind on the use of this epithet, and the eventual formal proposal was a taxon called Flexibacter maritimus (Wakabayashi et al. 1986, Holmes 1992). Reichenbach (1989) listed the pathogen as $C y$ tophaga marina, but the priority of the name Flexibacter maritimus was later recognized (Holmes 1992). These results were confirmed by Bernardet \& Grimont
(1989), who also validated the name Flexibacter maritimus based on DNA-DNA hybridisation methods.

However, the resolution of phenotypic characterization and 16S ribosomal RNA (rRNA) sequence analysis is insufficient to distinguish closely related organisms. Thus, Suzuki et al. (2001), based on the nucleotide sequence of the $g y r \mathrm{~B}$, proposed that Flexibacter maritimus should be transferred to the new genus Tenacibaculum, in which 7 members are currently included. Table 1 shows the main differential characteristics of the described species of the genus Tenacibaculum.

\section{GEOGRAPHICAL DISTRIBUTION AND HOST SPECIES}

The geographical distribution of Tenacibaculum maritimum in wild and farmed fish is shown in Table 2.

Table 1. Differential phenotypic characteristics of Tenacibaculum species. Data are from Wakabayashi et al. (1986), Hansen et al. (1992), Suzuki et al. (2001), Frette et al. (2004) and Yoon et al. (2005). +: positive; -: negative; W: weakly positive; V: variable reaction; ND: not determined; NG: no growth in the presence of $\mathrm{NaCl}$ only. All species are Gram-negative and rod-shaped. All species are positive for catalase, oxidase and degradation of casein

\begin{tabular}{|c|c|c|c|c|c|c|}
\hline Characteristic & T. maritimum & T. ovolyticum & T. mesophilum $T$ & T. amilotyticum & T. skagerrakense & T. lutimaris \\
\hline $\begin{array}{r}\text { Dis } \\
\text { bream }\end{array}$ & $\begin{array}{l}\text { iseased red sea } \\
\text { m fingerling, Japan }\end{array}$ & $\begin{array}{l}\text { Halibut egg, } \\
\text { Norway }\end{array}$ & $\begin{array}{c}\text { Sponge and } \\
\text { macroalgae, Japan }\end{array}$ & $\begin{array}{l}\text { Macroalgae, } \\
\text { Japan }\end{array}$ & $\begin{array}{l}\text { Pelagic, } \\
\text { Denmark }\end{array}$ & $\begin{array}{l}\text { Tidal flat, } \\
\text { Korea }\end{array}$ \\
\hline Cells size $(\mu \mathrm{m})$ & $2-30 \times 0.5$ & $2-20 \times 0.5$ & $1.5-10 \times 0.5$ & $2-4 \times 0.4$ & $2-15 \times 0.5$ & $2-10 \times 0.5$ \\
\hline \multicolumn{7}{|l|}{ Colony morphology } \\
\hline Shape & $\begin{array}{l}\text { Uneven } \\
\text { edge }\end{array}$ & $\begin{array}{l}\text { Regular } \\
\text { edge }\end{array}$ & $\begin{array}{c}\text { Circular or irregular, } \\
\text { spreading } \\
\text { edge }\end{array}$ & $\begin{array}{c}\text { Circular, } \\
\text { spreading } \\
\text { edge }\end{array}$ & $\begin{array}{l}\text { Circular, } \\
\text { spreading } \\
\text { edge }\end{array}$ & $\begin{array}{l}\text { Irregular, } \\
\text { spreading } \\
\text { edge }\end{array}$ \\
\hline Colour & Pale yellow & Pale yellow & Yellow & Yellow & Bright yellow & Pale yellow \\
\hline Temperature range $\left({ }^{\circ} \mathrm{C}\right)$ & $15-34$ & $4-25$ & $15-40$ & $20-35$ & $10-40$ & 10-39 \\
\hline Optimal temperature $\left({ }^{\circ} \mathrm{C}\right)$ & 30 & ND & $28-35$ & $27-30$ & $25-37$ & $30-37$ \\
\hline \multicolumn{7}{|l|}{ Salinity range } \\
\hline Seawater $(\%)^{a}$ & $30-100$ & $70-100$ & $10-100$ & $50-100$ & $25-150$ & ND \\
\hline $\mathrm{NaCl}(\%)^{\mathrm{b}}$ & NG & NG & $1-7$ & $3(\mathrm{~W})$ & NG & $2-3$ \\
\hline pH range & $5.9-8.6$ & $5.9-8.6$ & $5.3-9.0$ & $5.3-8.3$ & $6.0-9.0$ & $7.0-8.0$ \\
\hline \multicolumn{7}{|l|}{ Growth on: } \\
\hline Casamino acids & + & V & + & + & ND & + \\
\hline Sucrose & - & - & - & - & + & - \\
\hline D-ribose & - & - & - & - & ND & - \\
\hline DL-aspartate & - & - & + & - & + & - \\
\hline L-proline & - & - & + & + & + & - \\
\hline L-glutamate & $\mathrm{W}$ & - & + & + & + & - \\
\hline L-leucine & - & - & - & - & W & - \\
\hline \multicolumn{7}{|l|}{ Degradation of: } \\
\hline Starch & - & - & - & + & + & - \\
\hline Gelatin & + & + & + & + & ND & + \\
\hline Tween 80 & + & + & + & + & - & - \\
\hline Nitrate reduction & + & + & - & $\mathrm{W}$ & + & $\mathrm{V}(-)$ \\
\hline $\mathrm{G}+\mathrm{C}$ content $(\mathrm{mol} \%)$ & $31.3-32.5$ & $30.3-32$ & $31.6-32$ & 30.9 & 35.2 & $32.3-32.8$ \\
\hline
\end{tabular}


Table 2. Tenacibaculum maritimum. Geographic origin and host species identified to date

\begin{tabular}{|c|c|c|}
\hline Host species & Country & Source \\
\hline \multicolumn{3}{|l|}{ Asia } \\
\hline Black sea bream Acanthopagrus schlegeli & Japan & $\begin{array}{l}\text { Masumura \& Wakabayashi (1977), Wakabayashi et al. (1984, } \\
\text { 1986) }\end{array}$ \\
\hline Red sea bream Pagrus major & Japan & $\begin{array}{l}\text { Masumura \& Wakabayashi (1977), Wakabayashi et al. (1984, } \\
\text { 1986) }\end{array}$ \\
\hline Japanese flounder Paralichthys olivaceous & Japan & Baxa et al. (1986) \\
\hline Yellowtail Seriola quinqueradiata & Japan & Baxa et al. $(1988 b, c)$ \\
\hline Rock bream Oplegnathus fasciatus & Japan & Wakabayashi et al. (1986) \\
\hline \multicolumn{3}{|l|}{ Europe } \\
\hline Dover sole Solea solea & UK & $\begin{array}{l}\text { McVicar \& White (1979, 1982), Campbell \& Buswell (1982), } \\
\text { Bernardet et al. (1990) }\end{array}$ \\
\hline Sole Solea senegalensis & $\begin{array}{l}\text { Portugal } \\
\text { Spain }\end{array}$ & $\begin{array}{l}\text { Cepeda \& Santos (2002), Avendaño-Herrera et al. (2004b, 2005b) } \\
\text { Avendaño-Herrera et al. (2004b, 2005b) }\end{array}$ \\
\hline Sea bass Dicentrarchus labrax & $\begin{array}{l}\text { France } \\
\text { Malta } \\
\text { Italy }\end{array}$ & $\begin{array}{l}\text { Pépin \& Emeri (1993), Bernardet et al. (1994) } \\
\text { Bernardet (1998) } \\
\text { Salati et al. (2005) }\end{array}$ \\
\hline Turbot Scophthalmus maximus & Spain & $\begin{array}{l}\text { Devesa et al. (1989), Alsina \& Blanch (1993), } \\
\text { Pazos et al. 1993, Avendaño-Herrera et al. (2004a,b, 2005b) }\end{array}$ \\
\hline Atlantic salmon Salmo salar & Spain & Pazos et al. (1993) \\
\hline Gilthead seabream Sparus aurata & Spain & Avendaño-Herrera et al. (2004a,b) \\
\hline Tub gurnard Chelidonichthys lucerna & Italy & G. Magi (unpubl. data) \\
\hline \multicolumn{3}{|l|}{ Oceania } \\
\hline Atlantic salmon Salmo salar & Australia & $\begin{array}{l}\text { Soltani \& Burke (1994), Handlinger et al. (1997), Powell et al. } \\
\text { (2004) }\end{array}$ \\
\hline Rainbow trout Oncorhynchus mykiss & Australia & Soltani et al. (1996), Handlinger et al. (1997) \\
\hline Striped trumpeter Latris lineata & Australia & Handlinger et al. (1997) \\
\hline Greenback flounder Rhombosolea tapiriña & Australia & Soltani et al. (1996), Handlinger et al. (1997) \\
\hline Yellow-eye mullet Aldrichetta forsteri & Australia & Handlinger et al. (1997) \\
\hline Black bream Acanthopagrus butcheri & Australia & Handlinger et al. (1997) \\
\hline \multicolumn{3}{|l|}{ America } \\
\hline White sea bass Atractoscion nobilis & USA & Chen et al. (1995) \\
\hline Pacific sardine Sardinops sagax & USA & Chen et al. (1995) \\
\hline Northern anchovy Engraulis mordax & USA & Chen et al. (1995) \\
\hline Chinook salmon Oncorhynchus tschawytscha & USA & Chen et al. (1995) \\
\hline Atlantic salmon Salmo salar & Canada & Ostland et al. (1999) \\
\hline
\end{tabular}

Marine tenacibaculosis infection was first described by Masumura \& Wakabayashi (1977) as the cause of mortalities in red Pagrus major and black sea bream Acanthopagrus schlegeli, when a massive epizootic occurred in a hatchery in Hiroshima Prefecture (Japan). A few years later, the disease spread to other important cultured fish species in Japan such as Japanese flounder Paralichthys olivaceous and yellowtail Seriola quinqueradiata, among others (Baxa et al. 1986, Wakabayashi et al. 1986).

Despite the fact that tenacibaculosis has long been recognized as a disease of fish in Japan, the infection was not considered of economical importance until serious mortalities affecting Dover sole Solea solea in Scotland were reported by McVicar \& White (1979, 1982). The disease was later described as affecting sea bass Dicentrarchus labrax farmed on the Mediterranean coast of France (Pépin \& Emery 1993, Bernardet et al. 1994). Since 1990, as the farming of fish became a steadily growing industry, outbreaks of tenacibaculosis have also occurred in Spain and Portugal, mainly in turbot Scophthalmus maximus populations, Atlantic salmon Salmo salar and, lately, in sole Solea senegalensis and S. solea and gilthead seabream Sparus aurata (Devesa et al. 1989, Alsina \& Blanch 1993, Pazos et al. 1993, Cepeda \& Santos 2002, Avendaño-Herrera et al. 2004a,b, 2005b). Recently, Tenacibaculum maritimum has been isolated in Italy from sea bass (Salati et al. 2005) and tub gurnard Chelidonichthys lucerna (G. Magi unpubl. data).

In the southern hemisphere, Tenacibaculum maritimum has been identified in Australia as a pathogen of sea-caged Atlantic salmon and rainbow trout Oncorhynchus mykiss, captured striped trumpeter Latris lineata, greenback flounder Rhombosolea tapiriña, yellow-eye mullet Aldrichetta forsteri and black bream Acanthopagrus butcheri (Soltani \& Burke 1994, Handlinger et al. 1997). On the American continent, the 
microorganism has also been isolated from captured white sea bass Atractoscion nobilis, Pacific sardine Sardinops sagax and northern anchovy Engraulis mordax as well as Chinook salmon Oncorhynchus tschawytscha reared in marine net-pens along the southern Californian coast (Chen et al. 1995). Since then, outbreaks of tenacibaculosis have been reported in other geographical areas of North America, affecting Atlantic salmon smolts from British Columbia, Canada (Ostland et al. 1999). T. maritimum is suspected to be responsible for fish mortalities in Chile (Bernardet 1998), but the isolates have not been fully identified and, to our knowledge, no confirmation has as yet been published.

We believe that Tenacibaculum maritimum affects other host populations, in either cultured and/or wild fish; however, the failure to recover this pathogen from field samples, probably in part owing to its demanding growth requirements, makes the diagnosis of tenacibaculosis as well as the correct identification of the etiological agent difficult.

\section{ISOLATION AND PHENOTYPIC CHARACTERIZATION}

The isolation of Tenacibaculum maritimum using classical agar cultivation is difficult due to the slow growth of the bacterial cells and the overgrowth and/or inhibition produced by several other bacterial species present within the lesions (Pazos et al. 1996, Avendaño-Herrera et al. 2004a). The pathogen is an obligate marine microorganism and does not grow on media prepared only with $\mathrm{NaCl}_{\text {; }}$ it must be cultured on non-selective oligothrophic media that contain at least $30 \%$ seawater (Wakabayashi et al. 1986).

Since the first reports of tenacibaculosis, Anacker and Ordal agar (AOA) (Anacker \& Ordal 1959) or several modifications of this medium, prepared in $70 \%$ seawater, have been advocated for the isolation of seawater-dependent slow-growing Tenacibaculum maritimum from infected fish (Hikida et al. 1979, Wakabayashi et al. 1984, 1986, Bullock et al. 1986, Handlinger et al. 1997). Marine agar (Campbell \& Buswell 1982, Alsina \& Blanch 1993) and Hsu-Shotts media supplemented with antibiotics (Chen et al. 1995) have also been devised for the recovery and isolation of the pathogen. Other basal media, i.e. tryptone casamino acids yeast extract (Wakabayashi et al. 1984, 1986, Ostland et al. 1999), tryptone yeast extract salts (Toyama et al. 1996), tryptone yeast (Bader \& Shotts 1998) and 1/5 LBM (Marine Luria Broth) (Suzuki et al. 2001), have been described for laboratory culture and study of some physiological characteristic of $T$. maritimum, but they are not recommended for its isolation from environmental samples. In fact, although all these media support the growth of the T. maritimum strains, another medium named Flexibacter maritimus medium (FMM) (Pazos et al. 1996) has been proposed as the most appropriate for the successful isolation of this species from fish tissue. T. maritimum seems to grow better on this medium in comparison to heterotrophic halophilic bacteria such as Vibrio, Pseudomonas and Alteromonas spp., which are usually present in skin samples. This medium, as well as FMM prepared with commercial sea salts instead of seawater, has also been recommended for use in the routine drug susceptibility testing of this demanding pathogen (Avendaño-Herrera et al. 2005a). The incubation on most media is usually carried out at 20 to $25^{\circ} \mathrm{C}$ for 48 to $72 \mathrm{~h}$. In addition, it is important to note that only on FMM and AOA do the colonies exhibit the typical features described for this species - flat, pale-yellow with uneven edges and strongly adherent to the mediumwhereas on marine agar, colonies are round and show yellow pigment (Pazos et al. 1996).

The morphological, physiological and biochemical characteristics useful in the identification of Tenacibaculum maritimum have been detailed by several authors (Hikida et al. 1979, Baxa et al. 1986, Wakabayashi et al. 1986, Bernardet \& Grimont 1989, Bernardet et al. 1990, 1994, Alsina \& Blanch 1993, Pazos et al. 1993, Soltani \& Burke 1994, Chen et al. 1995, Ostland et al. 1999, Suzuki et al. 2001, Avendaño-Herrera et al. 2004b). These phenotypic results indicate that $T$. maritimum constitutes an homogeneous species, and they can be used for the identification of the pathogen. T. maritimum is a filamentous bacterium $0.5 \mu \mathrm{m}$ wide by 2 to $30 \mu \mathrm{m}$ long; however, occasionally cells up to $100 \mu \mathrm{m}$ in length can be observed. In older liquid and solid cultures, cells appear shorter and tend to become spherical (approximately $0.5 \mu \mathrm{m})$. Spheroplast-like forms are rarely observed even after prolonged incubation of the $T$. maritimum cells. Gliding motility on wet surfaces is a general feature of all isolates. The bacterium is mesophilic and can grow at temperatures from 15 to $34^{\circ} \mathrm{C}$, with an optimum growth temperature of $30^{\circ} \mathrm{C}$. On solid media, T. maritimum colonies absorb Congo red but the cells do not contain cell wall-associated flexirubin-type pigment. Different types of colonies, varying in their rhizoid aspect and adherence, may coexist on the same agar plate (Sorongon et al. 1991).

Tenacibaculum maritimum produces enzymes that degrade casein, tyrosine and tributyrin, but it does not hydrolyse agar, carboxymethyl cellulose, cellulose, starch, esculin, or chitin. Variable results have been reported for gelatin, hydrogen sulfide and nitrate reactions. As suggested by Suzuki et al. (2001), the employment of different basal media could account for this 
variability. Catalase and oxidase are positive in all strains. Regarding the use of carbohydrates, this pathogen is not able to degrade most of the simple and more complex carbohydrates. In addition, growth occurs on tryptone, casamino acids and yeast extract as the sole carbon and nitrogen source.

\section{SEROLOGICAL AND GENETIC STUDIES}

The first serological studies described by Wakabayashi et al. (1984) and Pazos et al. (1993), based on slide agglutination assays, reported antigenic homogeneity of Tenacibaculum maritimum, regardless of their origin and source of isolation. Further studies by Pazos (1997) and Ostland et al. (1999) demonstrated antigenic differences among $T$. maritimum isolates, suggesting that this microorganism may not be as homogeneous as previously thought. However, no agreement was reached among the serological groups established by these authors, perhaps due to differences in the antigens, antisera and the techniques used. Due to these discrepancies, major studies are necessary, since a clear definition of antigenic knowledge of this bacterial pathogen is of crucial importance for the development and formulation of appropriate and effective vaccine(s) (Romalde et al. 2005).

Dot blot assays and immunoblot analysis of lipopolysaccharides (LPS) revealed the existence of antigenic diversity in Tenacibaculum maritimum and demonstrated that at least 3 major O-serogroups seemingly related to the host species can be detected (Avendaño-Herrera et al. 2004b, 2005b). Thus, the majority of $T$. maritimum isolated from sole in the northwest of Spain and all gilthead sea bream isolates belonged to serotype O1, while all strains isolated from sole in Portugal and southern Spain constituted a serotype (O3), different from those strains isolated from turbot (serotype O2). However, this serological scheme could certainly be extended if further studies, including more strains of $T$. maritimum isolated from different hosts and/or geographical origins, are conducted. The analysis of total and outer membrane proteins revealed that all strains had common bands which are antigenically related.

From a genetic point of view, recent studies employing the random amplification polymorphic DNA polymerase chain reaction (RAPD-PCR) technique revealed the existence of genetic variability within the Tenacibaculum maritimum isolated from different marine fish. The strains were separated into 2 main clonal lineages that are strongly associated with the host and/or serogroups described for this pathogen (Avendaño-Herrera et al. 2004d). Interestingly, no plasmid band was detected in T. maritimum isolates using various methods (Avendaño-Herrera 2005). Therefore, the distinct RAPD profiles are not influenced by the presence of extra-chromosomal DNA. This finding constitutes the first evidence of genetic heterogeneity within this fish pathogen, and indicates that the RAPD analysis technique is a useful epizootiological tool for this bacterium.

\section{DIAGNOSTIC METHODS}

The presumptive diagnosis of tenacibaculosis is currently based on the clinical signs of the affected fish, particularly gross external lesions (described above), as well as in the microscopic examination of abundant long, thin, rod-shaped bacteria in wet mounts or Gram preparations obtained from gills or skin lesions of these symptomatic fish. However, the lack of visible Tenacibaculum maritimum in early lesions and the relative high incidence of secondary bacterial infections such as those caused by Vibrio spp. (Hikida et al. 1979, Kimura \& Kusuda 1983, Pépin \& Emery 1993, Handlinger et al. 1997) and saprophytic organisms, mainly ciliated protozoans (McVicar \& White 1979, Devesa et al. 1989) such as Trichodina and Uronema spp. (Chen et al. 1995, Handlinger et al. 1997), makes visualization difficult and increases the possibility of misdiagnosis.

Because isolation of the bacterium from diseased fish is not always successful, the definitive diagnosis must be supported by the isolation of colonies of Tenacibaculum maritimum on appropriate specific media, followed by the determination of at least a limited number of morphological and biochemical characteristics, or by the use of specific molecular DNA-based methods.

The homogeneity of Tenacibaculum maritimum facilitates the use of the miniaturized systems API ZYM and API 50CH for its identification (Bernardet \& Grimont 1989, Pazos et al. 1993, Bernardet et al. 1994, Chen et al. 1995, Ostland et al. 1999, Avendaño-Herrera et al. 2004b, 2005c). In fact, within the API ZYM gallery, the majority of isolates display a characteristic profile (positive results in the first 11 enzymatic reactions), whereas within the API $50 \mathrm{CH}$ not all $T$. maritimum strains were able to produce acid from any carbohydrate substrate. However, all these current microbiological methods based on culture and biochemical characterization are time-consuming. Therefore, procedures for rapid detection and identification of this pathogen are crucial for effective management and disease control in sea farming.

Slide agglutination did not prove to be a useful serological procedure for rapid identification of the bacterium due to the presence of auto-agglutinating 
strains (Avendaño-Herrera 2005). Fluorescent antibody techniques have also been used to detect this pathogen with contradictory results (Baxa et al. 1988a, Powell et al. 2004). These serological discrepancies, as well as the antigenic heterogeneity described above, suggest that a PCR methodology should be used as a powerful tool for an accurate identification of the pathogen from plate cultures as well as from tissues.

Two PCR primer pairs have been designed for the detection of Tenacibaculum maritimum using the $16 \mathrm{~S}$ rRNA gene as target. Toyama et al. (1996) selected a pair of primers MAR1 (5'-AATGGCATCGTTTTAAA3) and MAR2 (5'-CGCTCTCTGTTGCCAGA-3'), positions 190 to 206 and 1262 to 1278 , respectively, in the Escherichia coli 16S rRNA numbering system, flanking a $1088 \mathrm{bp}$ fragment. This could differentiate T. maritimum from the related species Flavobacterium branchiophilum and F. columnare, as well as from several other pathogenic bacteria. Then, Bader \& Shotts (1998) also selected a pair of $T$. maritimum species-specific PCR primers Mar1 (5'-TGTAGCTTGCTACAGATGA3') and Mar2 (5'-AAATACCTACTCGTAGGTACG-3'), positions 77 to 98 and 1060 to 1081, respectively, from unique sequence stretches within this gene, delimiting a 400 bp DNA fragment. Unfortunately, the authors only tested these primers with pure cultures, and not with infected fish tissues.

Recent research comparing the specificity and sensitivity of these 2 primer pairs demonstrated that the Toyama PCR procedure is the most adequate for an accurate detection of Tenacibaculum maritimum in diagnostic pathology, as well as in epidemiological studies of marine tenacibaculosis (Avendaño-Herrera et al. 2004c). Although this method proved useful in detecting acute $T$. maritimum infections in fish, the level of sensitivity was not sufficient to detect the pathogen when present in very low number in asymtomatic or carrier fish. In order to increase its sensitivity, a nested PCR approach was developed and was evaluated in experimentally seeded fish tissues and in field studies (Avendaño-Herrera et al. 2004a,c). The high level of $T$. maritimum found in mucus samples $\left(10^{3} \mathrm{CFU} \mathrm{ml}{ }^{-1}\right)$ indicates that this non-destructive method is very useful for a specific and rapid (only $7 \mathrm{~h}$ ) diagnosis of marine tenacibaculosis.

Other molecular methods that couple PCR amplification of 16S rDNA or 16S rRNA genes with a serological procedure or species-specific markers are also available for detecting Tenacibaculum maritimum. These include PCR-enzyme-linked immnosorbent assay (PCR-ELISA) (Wilson et al. 2002), reverse transcriptase polymerase chain reaction-enzyme hybridisation assay (RT-PCR-EHA) (Wilson \& Carson 2003) and DNA microarray probe (Warsen et al. 2004). These assays have shown sufficient sensitivity for the direct detec- tion of T. maritimum from pure culture, but the effectiveness in field conditions is still unknown. It is important to point out that the RT-PCR assay reported by Wilson \& Carson (2003) provided an important advance in the T. maritimum detection protocol because it gave a more accurate approximation of live bacterial carriage than conventional PCR.

\section{PATHOGENESIS OF INFECTION}

Despite the significance of Tenacibaculum maritimum in the aquaculture industry, relatively little is known about the pathogenicity of this bacterium. Various experimental infection studies have been carried out with varying rates of mortality depending on the different methods used to infect each marine fish species (Wakabayashi et al. 1984, Baxa et al. 1987, Alsina \& Blanch 1993, Bernardet et al. 1994, Soltani et al. 1996, Powell et al. 2004, 2005). This makes it difficult to fully understand of the mode of transmission and route of infection of this pathogen. Therefore, most of the information available has been described from naturally infected fish events.

The natural reservoir(s) of the pathogen have not been clarified yet because few data on the ecology of the microorganism exist; however, it can be isolated from sediment, the surface of tanks and from water cultures that have been exposed to infected stocks (Santos et al. 1999).

Some authors reported that natural outbreaks of tenacibaculosis occur a few weeks after transferring fish from hatchery tanks to inshore net cages (McVicar \& White 1979, Wakabayashi et al. 1984), suggesting that this agent may gain access to the host by horizontal transmission in seawater. However, recent survival experiments on Tenacibaculum maritimum using microcosms under natural conditions demonstrated an inhibitory effect of the natural aquatic microbiota on the growth and survival of this bacterium. In these experiments the pathogen remained culturable for only $5 \mathrm{~d}$ (Avendaño-Herrera et al. 2006a). A possible explanation for this is that all cells were lysed by the autochthonous microbiota, followed by rapid degradation of the DNA. However, we cannot rule out some influence of specific bacteriophages and protozoans on the survival of $T$. maritimum in the sea environment. Therefore, these results seem to suggest that seawater would not be an important route of transmission of $T$. maritimum.

It is well known that the primary sites of infection with Tenacibaculum maritimum are body surfaces such as the head, mouth, fins, and flanks (see review by Bernardet 1998). This pathogen attaches itself strongly to the external skin and mucus of fish which 
do not contain compounds that inhibits the growth of this bacterium (Magariños et al. 1995). The localization of the bacteria within the mucus layer suggests that $T$. maritimum could be part of the autochthonous populations of the fish skin, and therefore the pathogen can remain in the aquatic environment for a long time, utilizing fish mucus as a reservoir (Avendaño-Herrera 2005).

In the case of salmonids, the presence of the bacteria in the eyes and gills, where a necrotizing bronchitis occurs, is not uncommon (Chen et al. 1995, Handlinger et al. 1997). Powell et al. $(2004,2005)$ inoculated a high concentration of bacteria ( $10^{11}$ to $10^{12}$ cells per fish) on salmon gills, producing variable mortalities of fish, and they noted that respiratory damage occurred as a consequence of gill abrasion rather than infection with the bacterium. These findings indicate that the gills might not be an especially important route of infection for Tenacibaculum maritimum.

Tenacibaculum maritimum shows a lack of strict host specificity. Therefore, tenacibaculosis can be a risk for many species of anadromous and marine fish in which the disease has not been yet described. Although both adults and juveniles may be affected by tenacibaculosis, some authors have pointed out differences in the susceptibility of some fish species (i.e. red and black sea bream, sole, sea bass, salmonids and turbot) to the disease on the basis of fish age. Thus, whereas fish with body weights ranging from 2 to $80 \mathrm{~g}$ suffer the highest occurrence and a more severe form of the disease, fish above $100 \mathrm{~g}$ appear to be resistant (McVicar \& White 1979, Wakabayashi et al. 1984, Bernardet et al. 1994, Handlinger et al. 1997, Avendaño-Herrera 2005). This is due to the apparently greater susceptibility of smaller fish to T. maritimum (Bernardet et al. 1994), where the severe destruction of the affected tissues could progress from early stages to advanced ulcerative lesions within a few days.

To date, many of the studies on disease transmission support the hypothesis that Tenacibaculum maritimum is an opportunistic pathogen that primarly causes extensive skin damage and gill abrassion with subsequent systemic infection.

An increased prevalence and severity of the disease has been reported at higher temperatures (above $15^{\circ} \mathrm{C}$ ) and salinities (30 to $35 \%$ ) as well as with low water quality. However, winter outbreaks of tenacibaculosis have also been reported (Wakabayashi et al. 1984, Bernardet et al. 1994, Soltani et al. 1996). In addition to these factors, the disease is influenced by a multiplicity of environmental conditions (i.e. stress, excess of UV light, lack of sand substrate on the tank), management factors (i.e. high density and poor feeding) and host-related factors (skin surface condition)
(McVicar \& White 1979, 1982, Wakabayashi et al. 1984, Chen et al. 1995, Magariños et al. 1995, Handlinger et al. 1997). In these adverse conditions, the systemic disease involving different internal organs became more prevalent (Alsina \& Blanch 1993, Cepeda \& Santos 2002, Avendaño-Herrera et al. 2004b), indicating that Tenacibaculum maritimum has strong virulence mechanisms.

With regard to the mode(s) of infection, numerous researchers have investigated different methods to reproduce the disease in various fish species as well as to standardize an effective challenge model. Wakabayashi et al. (1984) and Baxa et al. (1987) demonstrated that bath challenge is not a reliable method of inducing the disease unless the skin is previously scarified or abraded (Bernardet et al. 1994) or the bacterial strain is first passaged twice in fish (Handlinger et al. 1997). However, fatal infections occurred when fish were exposed to topical application of Tenacibaculum maritimum culture on the surface of the mouth or tail (Wakabayashi et al. 1984). The intramuscular and intraperitoneal routes have been reported as not being effective in producing tenacibaculosis in experimentally infected red and black sea bream, sea bass or turbot (Wakabayashi et al. 1984, Alsina \& Blanch 1993, Pépin \& Emery 1993, Avendaño-Herrera et al. 2006b). Using the nestedPCR approach, we demonstrated that most of the $T$. maritimum inoculated in turbot are shed in the water within the first $6 \mathrm{~h}$ post-injection (Avendaño-Herrera et al. 2006b). This seems to be the reason why intraperitoneal injection is not effective in reproducing the disease.

Recent research efforts by our group led us to propose of an effective and reproducible infection model in turbot for tenacibaculosis infection. Thus, using prolonged immersion of fish for $18 \mathrm{~h}$ with the pathogen at 18 to $20^{\circ} \mathrm{C}$, the disease could be easily reproduced with the fish showing the classical signs of tenacibaculosis (Avendaño-Herrera et al. 2006b). This challenge model could be useful for future epizootiological studies and is essential for developing adequate measures to prevent and/or control tenacibaculosis.

In summary, it is conceivable that in the natural environment Tenacibaculum maritimum enters the host via a combination of routes including the horizontal transmission via food as described by Chen et al. (1995).

\section{VIRULENCE MECHANISMS}

A first prerequisite for the successful colonization of the host tissue is the ability to adhere. This may lead to a specific or non-specific form of attachment (Ofek \& Doyle 1994). Specific adhesion is mediated through 
specific compounds on the surface of the bacterium, which bind to receptors present on the host tissue. Non-specific adhesion depends on hydrophobic or ionic interactions between certain structures on the surface of the bacterium and the supporting substrate.

Burchard et al. (1990) reported that the capacity of adhesion of the Tenacibaculum maritimum cells significantly increases on substrates with low-critical energy surfaces (hydrophobic). Thus, the bacterium produces a substantial amount of extracellular polymers or 'slime', permitting them to adhere more firmly to hydrophobic surfaces than to those that are hydrophilic. The changes of the cell surface properties do not affect the action of gliding. These characteristics could be an advantage for $T$. maritimum and could explain why the cells systematically adhere onto different parts of the external tissue of fish once an infection has been established.

Adhesion of this pathogen cannot be explained by hydrophobic interactions alone. Sorongon et al. (1991) demonstrated with in vitro studies that growth conditions and nutrient availability provoke considerable changes in hydrophobicity and attachment of Tenacibaculum maritimum, which were accompanied by changes in the arrays of surface-exposed proteins. In static growth cultures, T. maritimum considerably increases the production of diverse polypeptides on the external cellular surface, at higher concentrations than those detected when the bacterium is grown in shaken liquid media.

Hemagglutinating activity, in addition to being a hydrophobic surface property, is sometimes associated with virulence. Pazos (1997) reported that Tenacibaculum maritimum cells agglutinate a broad spectrum of erythrocytes. Additional structures such as pili, fimbriae and flagella, known to be involved in adhesion and colonization of other bacteria (Toranzo \& Barja 1993, Toranzo et al. 2005), have not been observed in T. maritimum. Recent studies have demonstrated that T. maritimum isolates, regardless of their serotype, possess capsular material (Fig. 1) (Avendaño-Herrera 2005). Further studies are needed to elucidate its implication in the virulence mechanisms of this fish pathogen.

The adherence of this pathogen to host tissues depends directly on its ability to neutralize or evade the immune system of the fish, such as the bactericidal activity of mucus, and also on its ability to accumulate the nutrients required for its growth. Magariños et al. (1995) reported that Tenacibaculum maritimum, regardless of its origin and virulence degree, adhered strongly to the skin mucus of 3 fish species, and resisted its bactericidal properties.

With regard to the production of toxins in Tenacibaculum maritimum, Baxa et al. (1988b) conducted in vivo

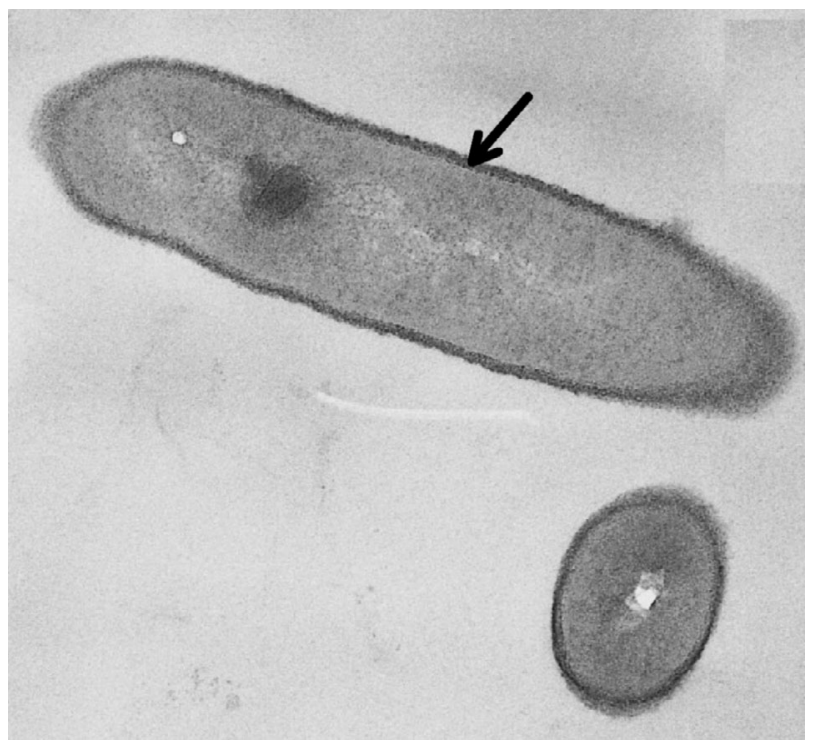

Fig. 1. Tenacibaculum maritimum. Transmission electron micrographs of thin sections of cells $(\times 22000)$. Arrow indicates a capsular structure strongly stained with ruthenium red

experiments in red and black sea bream, and concluded that the pathogenicity of this pathogen can be attributed to the synergistic interaction of the toxins and enzymes present in the extracellular products (ECP), which could facilitate the alteration and erosion of the host tissue and contribute to colonization and invasion. In fact, the ECP of this species possess very high proteolytic activity with an ability to degrade gelatin, amylase, casein and nucleases (Pazos 1997), as well as a positive cytotoxic activity in various fish cell lines.

It is known that LPS are responsible for some of the characteristic signs of disease in infections due to Gram-negative bacteria. The composition analysis of Tenacibaculum maritimum LPS revealed an O-chain composed of a disaccharide that contained an unusual linkage ([R]-2-hydroxyglutaric acid residue), which seems to be unique for this bacterium (Vinagradov et al. 2003). It has been suggested that this Ochain can contribute to the development of biofilms by the bacterium in the fish tissues (Vinagradov et al. 2003).

Another putative virulence factor examined in Tenacibaculum maritimum is its capacity to express high-affinity iron-uptake mechanisms, which can compete with the host iron-binding proteins. AvendañoHerrera et al. (2005c) have demonstrated that this bacterium, regardless of its serotype, grows and multiplies in the presence of the chelating agent ethilenediamine-di-(o-hydroxyphenyl acetic acid) (EDDHA) using at least 2 different systems of iron acquisition. 


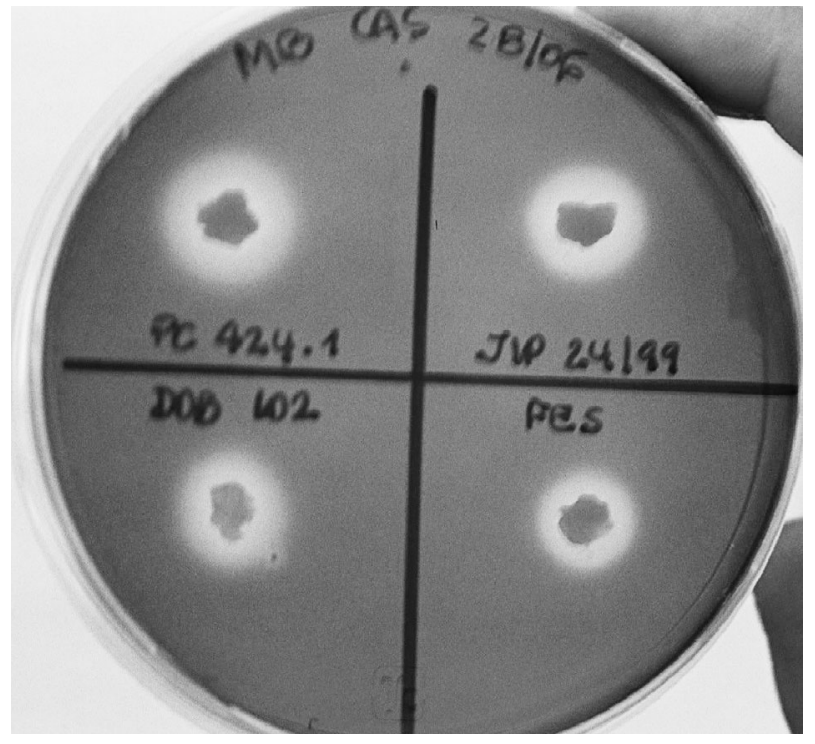

Fig. 2. Tenacibaculum maritimum. Modified chromoazurol S (CAS) agar assay for detecting siderophore production. Siderophore production is evidenced by the halo around the colony

One mechanism involves the production of an unidentified siderophore, which is neither a phenolate nor a hydroxamate type, as demonstrated by the chromoazurol S (CAS) agar (Fig. 2) and liquid tests. The second mechanism allows the utilization of heme groups (hemin or haemoglobin) as an iron source by direct binding (Fig. 3). In addition, it has also been reported that intraperitoneal injection of hemin before experimental infection increased the lethality of this pathogen (Avendaño-Herrera 2005).

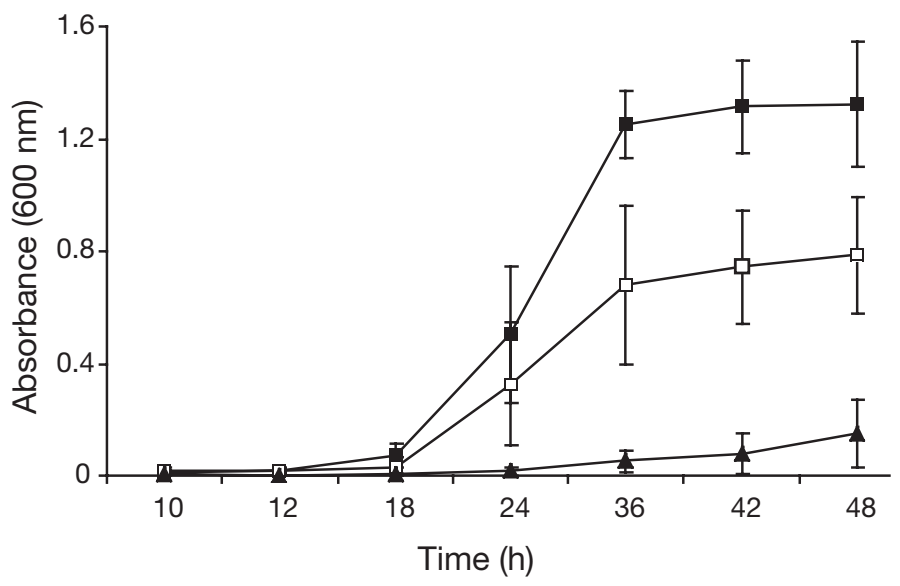

Fig. 3. Tenacibaculum maritimum. Average growth of strains utilizing hemoglobin $5 \mu \mathrm{M}(\square)$ and hemin $5 \mu \mathrm{M}(\square)$ as an iron source in FMM medium containing EDDHA. Cells cultured under iron-restricted conditions ( $\mathbf{\Lambda})$ were used as negative control. Bars: SD from 3 different strains tested
The lack of plasmids in this pathogen indicate that the expression of the putative virulence factors present in this bacterium must be chromosome-coded.

\section{TREATMENT AND PREVENTION OF TENACIBACULOSIS}

\section{Chemotherapy}

In vitro studies on the susceptibility of Tenacibaculum maritimum to various chemotherapeutic agents indicate that bacterial strains isolated from different host species and geographical regions exhibit a similar pattern, with respect to susceptibility to nitrofurans, penicillins, erythromycin, tetracyclines, chloramphenicol, trimethoprim, potentiated sulfonamides and fluoroquinolones, and resistance to colistin, kanamicyn, neomicyn and the quinolones, oxolinic acid and flumequine (Baxa et al. 1988c, Alsina \& Blanch 1993, Pazos et al. 1993, Chen et al. 1995, Soltani et al. 1995, Avendaño-Herrera et al. 2004b, 2005a). However, field results were not always similar even if the isolated bacteria were highly sensitive (in vitro) to the drug used for treating the condition (Cepeda \& Santos 2002).

In practice, variable results were achieved using oral medication and/or bath treatment. The first data on tenacibaculosis control using drugs was reported by McVicar \& White (1979) in Scotland. After applying a broad antibiotic spectrum to sole (i.e. furanace, terramicine, kanamycin, Tribrissen and Tylan) by oral treatment, the authors did not observe any decrease in mortality. In contrast, the administration of streptomycin sulphate and penicillin by immersion were effective, but both with only short-term results (McVicar \& White 1979). It is well know that when infection occurs, fish do not take the medicated feed, and they become anorexic immediately post-infection; thus, bath treatment seems to be more effective than the oral treatment, as reported by Soltani et al. (1995). In addition, these authors showed by means of laboratory and field trials that the administration of amoxycillin and trimethoprim is an effective antimicrobial therapy against Tenacibaculum maritimum, producing adequate serum levels when given by oral or immersion procedures to Atlantic salmon and rainbow trout. Treatments with oxytetracycline in salmonids (Handlinger et al. 1997) and furazolidone in turbot (Alsina \& Blanch 1993) were also reported to control the disease. Unfortunately, the use of this last drug in fish farms is not permitted in the majority of salmon-farming countries.

Among the drugs used in the past few years in turbot and sole cultures (tetracycline, enrofloxacin, flumequine and potentiated sulfonamides), enrofloxacin proved to be the most useful compound for controlling 
Tenacibaculum maritimum outbreaks, although the rapid appearance of resistant strains has already been described (Avendaño-Herrera 2005).

\section{Other prophylatic treatments}

An alternative to drugs would be the use of surfaceacting disinfectants administered by immersion. Routine formalin treatments (30 to $40 \mathrm{ppm}$ bath for $6 \mathrm{~h}$ ) were effective in the control of tenacibaculosis in Dover sole (McVicar \& White 1979). However, gill problems associated with the prolonged use of this compound were noted by the same authors. On the other hand, some hatchery managers have expressed concern about user sensitization to formalin and its environmental impact. In addition, this compound is expensive, as well as difficult to use and store. Potassium permanganate has also been used, mainly for water disinfection, to control disease outbreaks in penreared sea bass in Malta (Bernardet 1998). Hydrogen peroxide $\left(\mathrm{H}_{2} \mathrm{O}_{2}\right)$ has recently received attention for its effective control of numerous external pathogens to fish. In the case of Tenacibaculum maritimum, Avendaño-Herrera (2005) recommended the use of $\mathrm{H}_{2} \mathrm{O}_{2}$ at a concentration of 240 ppm only as a general disinfection method for treating water culture and the surface of tanks before the introduction of fish.

Manipulation of temperature and/or salinity can be used to reduce the morbidity produced by Tenacibaculum maritimum in salmonids; Soltani \& Burke (1994) recommended maintaining the temperature around $15^{\circ} \mathrm{C}$ and salinity below $10 \mathrm{~g} \mathrm{l}^{-1}$. The appearance of outbreaks can also be avoided or the incidence of the disease can be reduced by controlling fish densities (avoiding overcrowding), reducing stress conditions, and avoiding overfeeding (McVicar \& White 1982, Soltani et al. 1996). Sand substrate has been added to tanks to prevent the occurrence of tencibaculosis and has cured an established disease situation in Dover sole (McVicar \& White 1979, 1982). Although all these measures help prevent the disease, modifying husbandry parameters will probably involve related technical problems. Therefore, immunoprophylaxis have become the best way to prevent tenacibaculosis.

\section{Vaccines}

In spite of the severe impact of this disease, relatively few attempts at vaccination have been described and were unknown until the end of the 1990s. To date, there is a general agreement that a vaccine would considerably help to control tenacibaculosis and various groups have established research programs with the aim of developing a vaccine in Spain and Australia (Håstein et al. 2005). At present, only 1 bacterin is commercially available to prevent turbot mortalities caused by Tenacibaculum maritimum. As the disease affects juvenile and adult turbot, the vaccine is applied by bath when the fish are 1 to $2 \mathrm{~g}$, followed by a booster injection when they attain 20 to $30 \mathrm{~g}$. Whereas the relative percentage of survival (RPS) following bath immunization is about $50 \%$, the protection increases above $85 \%$ after intraperitoneal (i.p.) booster injection (Toranzo et al. 2004). The regular use of this vaccine in some turbot farms has reduced the incidence of tenacibaculosis. However, the serological diversity described above indicates that the vaccine developed for turbot may not be effective in preventing the tenacibaculosis in other fish species. Therefore, a new tenacibaculosis bacterin specific for cultured sole is currently being developed and evaluated by our research group. We have demonstrated that this confers RPS values higher than $90 \%$ in laboratory trials by i.p. injection (Romalde et al. 2005). The studies published on immunization in Australia are scarce. Carson et al. (1993) compared the effectiveness of different bacterins in cultured salmonids and showed that the $T$. maritimum vaccines rendered variable protection levels ranging from 21 to $70 \%$.

Similar to other fish vaccines, it seems that the LPS are the main protective antigen of this pathogen (Salati et al. 2005).

\section{CONCLUSIONS}

We have reviewed the current knowledge about tenacibaculosis in fish and its etiological agent, Tenacibaculum maritimum. Despite efforts made in the past 10 years to deal with the problems discussed above, it is obvious that the pathogenesis of T. maritimum is a complex, multifactorial process not yet fully understood. There are considerable gaps concerning (1) the route of transmission and reservoir, (2) the survival strategies of this pathogen, an understanding of which would be helpful in developing adequate preventive control programs against marine tenacibaculosis, (3) other possible virulence mechanisms, e.g. the capsule, (4) the pharmacokinetics of drugs in susceptible cultured fish and (5) the establishment of adequate vaccination programmes for economically important marine fish.

Acknowledgements. This review was based in part on work supported by Grants PETRI95-0657.01.OP, AGL2004-07037 and ACU01-012 from the Ministerio de Ciencia y Tecnología (Spain). R.A.H. thanks Programs BID-CONICYT, Chile, for the postgraduate fellowship. 


\section{LITERATURE CITED}

Alsina M, Blanch AR (1993) First isolation of Flexibacter maritimus from cultivated turbot (Scophthalmus maximus). Bull Eur Assoc Fish Pathol 13:157-160

Anacker RL, Ordal EJ (1959) Studies on the myxobacterium Chondrococcus columnaris. I. Serological typing. J Bacteriol 78:25-32

Avendaño-Herrera R (2005) Avances en el conocimiento del patógeno de peces Tenacibaculum maritimum: implicaciones en el diagnóstico y prevención de la enfermedad. $\mathrm{PhD}$ thesis, Universidad de Santiago de Compostela

Avendaño-Herrera R, Núñez $\mathrm{S}$, Magariños B, Toranzo AE (2004a) A non-destructive method for rapid detection of Tenacibaculum maritimum in farmed fish using nested PCR amplification. Bull Eur Assoc Fish Pathol 24:280-286

Avendaño-Herrera R, Magariños B, López-Romalde S, Romalde JL, Toranzo AE (2004b) Phenotypic characterization and description of two major O-serotypes in Tenacibaculum maritimum strains from marine fish. Dis Aquat Org $58: 1-8$

Avendaño-Herrera R, Magariños B, Toranzo AE, Beaz R, Romalde JL (2004c) Species-specific polymerase chain reaction primer sets for the diagnosis of Tenacibaculum maritimum infection. Dis Aquat Org 62:75-83

Avendaño-Herrera R, Rodríguez J, Magariños B, Romalde JL, Toranzo AE (2004d) Intraspecific diversity of the marine fish pathogen Tenacibaculum maritimum as determined by randomly amplified polymorphic DNA-PCR. J Appl Microbiol 96:871-877

Avendaño-Herrera $R$, Irgang $R$, Núñez $S$, Romalde JL, Toranzo AE (2005a) Recommendation of an appropriate medium for in vitro drug susceptibility testing of the fish pathogen Tenacibaculum maritimum. Antimicrob Agents Chemother 49:82-87

Avendaño-Herrera R, Magariños B, Moriñigo MA, Romalde JL, Toranzo AE (2005b) A novel O-serotype in Tenacibaculum maritimum strains isolated from cultured sole (Solea senegalensis). Bull Eur Assoc Fish Pathol 25:70-74

Avendaño-Herrera R, Toranzo AE, Romalde JL, Lemos ML, Magariños B (2005c) Iron uptake mechanisms in the fish pathogen Tenacibaculum maritimum. Appl Environ Microbiol 71:6947-6953

Avendaño-Herrera R, Irgang R, Magariños B, Romalde JL, Toranzo AE (2006a) Use of microcosm to determine the survival of the fish pathogen Tenacibaculum maritimum in seawater. Environ Microbiol 8:921-928

Avendaño-Herrera R, Toranzo AE, Magariños B (2006b) A challenge model for Tenacibaculum maritimum infection in turbot (Scophthalmus maximus). J Fish Dis 29:1-4

Bader JA, Shotts EB (1998) Identification of Flavobacterium and Flexibacter species by species-specific polymerase chain reaction primers to the $16 \mathrm{~S}$ ribosomal RNA gene. J Aquat Anim Health 10:311-319

Baxa DV, Kawai K, Kusuda R (1986) Characteristics of gliding bacteria isolated from diseased cultured flounder, Paralichthys olivaceous. Fish Pathol 21:251-258

Baxa DV, Kawai K, Kusuda R (1987) Experimental infection of Flexibacter maritimus in black sea bream (Acanthopagrus schlegeli) fry. Fish Pathol 22:105-109

Baxa DV, Kawai K, Kusuda R (1988a) Detection of Flexibacter maritimus by fluorescent antibody technique in experimentally infected black sea bream fry. Fish Pathol 23: 29-32

Baxa DV, Kawai K, Kusuda R (1988b) In vitro and in vivo activities of Flexibacter maritimus toxins. Rep Usa Mar Biol Inst Kochi Univ 10:1-8
Baxa DV, Kawai K, Kusuda R (1988c) Chemotherapy of Flexibacter maritimus infection. Rep Usa Mar Biol Inst Kochi Univ 10:9-14

Bernardet JF (1998) Cytophaga, Flavobacterium, Flexibacter and Chryseobacterium infections in cultured marine fish. Fish Pathol 33:229-238

Bernardet JF, Grimont PA (1989) Deoxyribonucleic acid relatedness and phenotypic characterization of Flexibacter columnaris sp. nov., nom. rev., Flexibacter psychrophilus sp. nov., nom. rev., and Flexibacter maritimus Wakabayashi, Hikida, and Masumura 1986. Int J Syst Bacteriol 39:346-354

Bernardet JF, Campbell AC, Buswell JA (1990) Flexibacter maritimus is the agent of 'black patch necrosis' in Dover sole in Scotland. Dis Aquat Org 8:233-237

Bernardet JF, Kerouault B, Michel C (1994) Comparative study on Flexibacter maritimus strains isolated from farmed sea bass (Dicentrarchus labrax) in France. Fish Pathol 29:105-111

Bullock GL, Hsu TC, Shotts Jr EB (1986) Columnaris disease of fishes. Fish Dis Leafl 72, US Dep Inter Fish Wildl Serv, Washington, DC

Burchard RP, Rittschof D, Bonaventura J (1990) Adhesion and motility of gliding bacteria on substrata with different surface free energies. Appl Environ Microbiol 56:2529-2534

Campbell AC, Buswell JA (1982) An investigation into the bacterial aetiology of 'black patch necrosis' in Dover sole, Solea solea L. J Fish Dis 5:495-508

Carson J, Schmidtke L, Lewis T (1993) Development of a vaccine against disease. Results of efficacy testing of three types of vaccine. In: Valentine P (ed) Barriers and breakthroughs. Research and Development Review Seminar, Hobart, p 149-158

Cepeda C, Santos Y (2002) First isolation of Flexibacter maritimus from farmed Senegalese sole (Solea senegalensis, Kaup) in Spain. Bull Eur Assoc Fish Pathol 22:388-392

Chen MF, Henry-Ford D, Groff JM (1995) Isolation and characterization of Flexibacter maritimus from marine fishes of California. J Aquat Anim Health 7:318-326

Devesa S, Barja JL, Toranzo AE (1989) Ulcerative skin and fin lesions in reared turbot, Scophthalmus maximus (L). J Fish Dis 12:323-333

Frette L, Jørgensen NO, Irming H, Kroer N (2004) Tenacibaculum skagerrakense sp. nov., a marine bacterium isolated from the pelagic zone in Skagerrak, Denmark. Int J Syst Evol Microbiol 54:519-524

Handlinger J, Soltani M, Percival S (1997) The pathology of Flexibacter maritimus in aquaculture species in Tasmania, Australia. J Fish Dis 20:159-168

Hansen GH, Bergh Ø, Michaelsen J, Knappskog D (1992) Flexibacter ovolyticus sp. nov., a pathogen of eggs and larvae of Atlantic halibut, Hippoglossus hippoglossus L. Int J Syst Bacteriol 42:451-458

Håstein T, Gudding R, Evensen $\varnothing$ (2005) Bacterial vaccines for fish-an update of the current situation worldwide. In: Midtlyng PJ (ed) Progress in fish vaccinology. Developments in biologicals, Vol 121. Karger, Basel, p 55-74

Hikida M, Wayabayashi H, Egusa S, Masumura K (1979) Flexibacter sp., a gliding bacterium pathogenic to some marine fishes in Japan. Bull Jpn Soc Sci Fish 45:421-428

Holmes B (1992) Synonymy of Flexibacter maritimus Wakabayashi, Hikida, and Masumura 1986 and Cytophaga marina Reichenbach 1989. Int J Syst Bacteriol 42:185

Kimura H, Kusuda R (1983) Microbial succession in gliding bacterium infection in red sea bream. Bull Jpn Soc Sci Fish 49:1553-1559

Magariños B, Pazos F, Santos Y, Romalde JL, Toranzo AE 
(1995) Response of Pasteurella piscicida and Flexibacter maritimus to skin mucus of marine fish. Dis Aquat Org 21: 103-108

Masumura K, Wakabayashi H (1977) An outbreak of gliding bacterial disease in hatchery-born red seabream (Pagrus major) and gilthead (Acanthopagrus schlegeli) fry in Hiroshima. Fish Pathol 12:171-177

McVicar AH, White PG (1979) Fin and skin necrosis of cultivated Dover sole Solea solea (L). J Fish Dis 2:557-562

McVicar AH, White PG (1982) The prevention and cure of an infectious disease in cultivated juvenile Dover sole, Solea solea (L.). Aquaculture 26:213-222

Ofek I, Doyle RJ (1994) Bacterial adhesion to cells and tissues. Chapman \& Hall, New York

Ostland VE, LaTrace C, Morrison D, Ferguson HW (1999) Flexibacter maritimus associated with a bacterial stomatitis in Atlantic salmon smolts reared in net-pens in British Columbia. J Aquat Anim Health 11:35-44

Pazos F (1997) Flexibacter maritimus: estudio fenotípico, inmunológico y molecular. PhD thesis, Universidad Santiago de Compostela

Pazos F, Santos Y, Núñez S, Toranzo AE (1993) Increasing occurrence of Flexibacter maritimus in the marine aquaculture of Spain. FHS/AFS Newsl 21:1-2

Pazos F, Santos Y, Macías AR, Núñez S, Toranzo AE (1996) Evaluation of media for the successful culture of Flexibacter maritimus. J Fish Dis 19:193-197

Pépin JF, Emery E (1993) Marine Cytophaga-like bacteria (CLB) isolated from diseased reared sea bass (Dicentrarchus labrax L.) from French Mediterranean coast. Bull Eur Assoc Fish Pathol 13:165-167

Powell MD, Carson J, van Gelderen R (2004) Experimental induction of gill disease in Atlantic salmon Salmo salar smolts with Tenacibaculum maritimum. Dis Aquat Org 61: 179-185

Powell MD, Harris JO, Carson J, Hill JV (2005) Effects of gill abrasion and experimental infection with Tenacibaculum maritimum on the respiratory physiology of Atlantic salmon Salmo salar affected by amoebic gill disease. Dis Aquat Org 63:169-174

Reichenbach H (1989) Family I. Cytophagaceae. In: Staley JT, Bryant MP, Pfenning N, Holt JG (eds) Bergey's manual of systematic bacteriology, Vol 3. Williams and Wilkins, Baltimore, MD, p 2013-2050

Romalde JL, Ravelo C, López-Romalde S, Avendaño-Herrera R, Magariños B, Toranzo AE (2005) Vaccination strategies to prevent important emerging diseases for Spanish aquaculture. In: Midtlyng PJ (ed) Progress in fish vaccinology. Developments in biologicals, Vol 121. Karger, Basel, p 85-95

Salati F, Cubadda C, Viale I, Kusuda R (2005) Immune response of sea bass Dicentrarchus labrax to Tenacibaculum maritimum antigens. Fish Sci 71:563-567

Santos Y, Pazos F, Barja JL (1999) Flexibacter maritimus, causal agent of flexibacteriosis in marine fish. In: Oliver G (ed) ICES identification leaflets for diseases and parasites of fish and shellfish, No. 55. ICES, Copenhagen, p 1-6

Soltani M, Burke CM (1994) Responses of fish-pathogenic

Editorial responsibility: David W. Bruno,

Aberdeen, UK
Cytophaga/Flexibacter-like bacteria (CFLB) to environmental conditions. Bull Eur Assoc Fish Pathol 14: $185-187$

Soltani M, Shanker S, Munday BL (1995) Chemotherapy of Cytophaga/Flexibacter-like bacteria (CFLB) infections in fish: studies validating clinical efficacies of selected antimicrobials. J Fish Dis 18:555-565

Soltani M, Munday BL, Burke CM (1996) The relative susceptibility of fish to infections by Flexibacter columnaris and Flexibacter maritimus. Aquaculture 140:259-264

Sorongon ML, Bloodgood RA, Burchard RP (1991) Hydrophobicity, adhesion, and surface-exposed proteins of gliding bacteria. Appl Environ Microbiol 57:3193-3199

Suzuki M, Nakagawa Y, Harayama S, Yamamoto S (2001) Phylogenetic analysis and taxonomic study of marine Cytophaga-like bacteria: proposal for Tenacibaculum gen. nov. with Tenacibaculum maritimum comb. nov. and Tenacibaculum ovolyticum comb. nov., and description of Tenacibaculum mesophilum sp. nov. and Tenacibaculum amylolyticum sp. nov. Int J Syst Evol Microbiol 51: 1639-1652

Toranzo AE, Barja JL (1993) Virulence factors of bacteria pathogenic for coldwater fish. Annu Rev Fish Dis 3:5-36

Toranzo AE, Romalde JL, Dopazo CP, Magariños B, Barja JL (2004) Disease trends in the primary marine fish species cultured in Spain: a 20-year study. World Aquacult 35: $35-38$

Toranzo AE, Magariños B, Romalde JL (2005) A review of the main bacterial fish diseases in mariculture system. Aquaculture 246:37-61

Toyama T, Kita-Tsukamoto K, Wakabayashi H (1996) Identification of Flexibacter maritimus, Flavobacterium branchiophilum and Cytophaga columnaris by PCR targeted 16S ribosomal DNA. Fish Pathol 31:25-31

Vinogradov E, MacLean LL, Crump EM, Perry MB, Kay WW (2003) Structure of the polysaccharide chain of the lipopolysaccharide from Flexibacter maritimus. Eur J Biochem 270:1810-1815

Wakabayashi H, Hikida M, Masumura K (1984) Flexibacter infection in cultured marine fish in Japan. Helgol Meeresunters 37:587-593

Wakabayashi H, Hikida M, Masumura K (1986) Flexibacter maritimus sp. nov., a pathogen of marine fishes. Int J Syst Bacteriol 36:396-398

Warsen AE, Krug MJ, LaFrentz S, Stanek DR, Loge FJ, Call DR (2004) Simultaneous discrimination between 15 fish pathogens by using $16 \mathrm{~S}$ ribosomal DNA PCR and DNA microarrays. Appl Environ Microbiol 70:4216-4221

Wilson T, Carson J (2003) Development of sensitive, highthroughput one-tube RT-PCR-enzyme hybridization assay to detect selected bacterial fish pathogens. Dis Aquat Org 54:127-134

Wilson T, Carson J, Bowman J (2002) Optimization of onetube PCR-ELISA to detect femtogram amounts of genomic DNA. J Microbiol Methods 51:163-170

Yoon JH, Kang SJ, Oh TK (2005) Tenacibaculum lutimaris sp. nov., isolated from a tidal flat in the yellow Sea, Korea. Int J Syst Evol Microbiol 55:793-798

Submitted: February 4, 2006; Accepted: May 7, 2006

Proofs received from author(s): July 27, 2006 